\title{
Synthesis of ferrocene- and azobenzene-based compounds for anion recognition
}

\author{
Xiao-ting ZHAI, Hao-jie YU ${ }^{\dagger \ddagger}$, Li WANG ${ }^{\dagger \ddagger}$, Zheng DENG, Zain-ul ABDIN, Yong-sheng CHEN \\ (The State Key Laboratory of Chemical Engineering, College of Chemical and Biological Engineering, \\ Zhejiang University, Hangzhou 310027, China) \\ †E-mail: hjyu@zju.edu.cn; opl_wl@dial.zju.edu.cn
}

Received July 22, 2015; Revision accepted Oct. 8, 2015; Crosschecked Jan. 25, 2016

\begin{abstract}
A series of ferrocene- and azobenzene-based compounds with acyl amine groups attached were designed and synthesized to explore their potential application in anion recognition. Their electro- and photo-properties, and the effect of nitro and amine substituents of the benzene ring on anion recognition were studied by UV-vis absorption spectroscopy (UV) and cyclic voltammetry $(\mathrm{CV})$. The results showed that a nitro group substituent has a positive effect on the binding affinity and sensitivity, which might be due to the strong hydrogen bonding interaction between the receptor and the guest, while an amino group substituent has a negative effect on the sensitivity. Furthermore, the shift in the UV-vis absorption spectra was observed as a color change, which can be used for the naked-eye detection of $\mathrm{F}^{-}$and $\mathrm{H}_{2} \mathrm{PO}_{4}^{-}$.
\end{abstract}

Key words: Ferrocene, Azobenzene, Hydrogen bonding, High density information storage, Anion recognition http://dx.doi.org/10.1631/jzus.A1500183

CLC number: O69

\section{Introduction}

Ferrocene and its derivatives have been popular subjects of research because of their useful electrochemical activity, thermal stability, and liquid crystalline properties (Seibold and Sutton, 1955; Manners, 1999; Apreutesei et al., 2007; Lisa et al., 2010; Onofrei et al., 2012). On the other hand, azobenzene and its derivatives are well-known for their perfect opto-chemical properties since the azo group can undergo isomerization between trans- and cis- form through alternate irradiation of UV and visible light

\footnotetext{
Corresponding authors

* Project supported by the National Natural Science Foundation of China (Nos. 21272210, 21472168, 21372200, and 21411130187), the International Science and Technology Cooperation Project of the Ministry of Science and Technology of China (No. 2009DFR40640), the Science and Technology Program of Zhejiang Province (Nos. 2013C24001 and 2013C31146), and the Science and Technology Innovation Team of Ningbo City (No. 2011B82002), China (D) ORCID: Hao-jie YU, http://orcid.org/0000-0002-7405-7881 (c) Zhejiang University and Springer-Verlag Berlin Heidelberg 2016
}

(Kumar and Neckers, 1989; Ikeda and Tsutsumi, 1995; Natansohn and Rochon, 2002). What is noteworthy is that, on combination of these two units in one compound, the ferrocenyl center affects the isomerization behavior of azobenzene by intramolecular interaction. On account of this phenomenon, many efforts have been done to synthesize multifunctional compounds containing both ferrocene and azobenzene units (Kurosawa et al., 1999; Shafir et al., 2000; Namiki et al., 2011; Amer et al., 2013). The resultant products have shown various applications in different fields such as chemical sensors, molecular devices, liquid crystalline materials, and high-density information storage materials, etc. (Sakamoto et al., 2005; Muraoka et al., 2006; 2007; Carlescu et al., 2007; Sola et al., 2012; Onofrei et al., 2013).

With the rapid development of the economy, environmental issues are becoming more important and it is necessary to detect anions such as $\mathrm{F}^{-}$and $\mathrm{H}_{2} \mathrm{PO}_{4}^{-}$, which will, above certain concentrations, 
harm the environment, the ecological balance, and people's health. Recognition and sensing of anions is usually based on interactions such as hydrogenbonding and electrostatic interaction (Thomas et al., 2000; Reynes et al., 2004; Szymanska et al., 2006; Yoon et al., 2006; Villoslada et al., 2009; Li et al., 2013). Acyl amino and ureido groups are promising candidates for binding specific organic anions due to their specific chemical structures (Beer et al., 1997; Kuo et al., 2003; Miyaji et al., 2003; Oton et al., 2004). Furthermore, effective signal transmission units are needed in anion recognition. Ferrocene and azobenzene are well known electro- and photoresponsive units which thus have advantages in signal transmission for anion recognition. As far as we know, double signal responsive recognition molecules have advantages for the detection of specific anions with more accuracy. Our previous research showed that ferrocene-containing azobenzene-based probe molecules have high selectivity and sensitivity toward $\mathrm{F}^{-}$and $\mathrm{H}_{2} \mathrm{PO}_{4}^{-}$accompanied by color changes (Li et al., 2013). However, the effect of different kinds of substituent groups was not studied.

In this research, three ferrocenyl azobenzenes, substituted with amino and nitro groups, were synthesized and their sensitivity and selectivity toward $\mathrm{F}^{-}$and $\mathrm{H}_{2} \mathrm{PO}_{4}^{-}$were studied and the effect of different substituent groups on anion recognition behaviour was explored. The photo-chemical and electro-chemical properties and recognition behavior of the synthesized compounds were investigated through UV-vis absorption spectroscopy (UV) and cyclic voltammetry $(\mathrm{CV})$ studies, respectively. The most interesting finding was that the nitro group has a positive effect on the binding affinity and sensitivity between the probe molecules and specific anions, while the amino group substituent has a negative effect on that sensitivity.

\section{Experimental}

\subsection{Materials}

Tetrahydrofuran (THF, analytical reagent (AR)), dichloromethane (DCM, AR), dimethyl sulfoxide (DMSO, AR), ethanol (AR), and triethylamine $\left(\mathrm{Et}_{3} \mathrm{~N}, \mathrm{AR}\right)$ were purchased from Sinopharm Chemical Reagent Co., Ltd. Tetrabutylammonium fluoride hydrate $(98 \%)$ and tetrabutylammonium chloride (98\%) were purchased from Tokyo Chemical Industry Co., Ltd. Tetrabutylammonium iodide (99\%), tetrabutylammonium hydrogen sulfate $(99 \%)$, tetrabutylammonium bromide $(99 \%)$, tetrabutylammonium phosphate $(99 \%)$, and sodium sulfide nonahydrate were supplied by J\&K Scientific Ltd. Disperse orange $3(90 \%)$ was purchased from Thermo Fisher Scientific. Ferrocene carbonate acid and 1,1'-ferrocenedicarboxylic acid were supplied by China National Pharmaceutical Group Chemical Co., Ltd. DCM and $\mathrm{Et}_{3} \mathrm{~N}$ were used after drying by 4A-type molecular sieves followed by distillation over calcium hydride, while THF was used after drying by 4A-type molecular sieves followed by distillation over potassium. Other chemicals were used as received.

\subsection{Characterization}

The ${ }^{1} \mathrm{H}$ NMR and ${ }^{13} \mathrm{C}$ NMR spectra of the synthesized ferrocenyl azobenzene $\mathbf{1}, \mathbf{2}$, and $\mathbf{3}$ were recorded on a $400 \mathrm{MHz}$ AVANCE DMX spectrometer instrument and $500 \mathrm{MHz}$ AVANCE DMX spectrometer instrument with deuterated DMSO as the solvent, respectively. Fourier transform infrared (FTIR) spectra were recorded on a Jasco IR-700 infrared spectrophotometer within $400-4000 \mathrm{~cm}^{-1}$ by incorporating samples in $\mathrm{KBr}$ disks.

The CV curves were recorded on a CHI-630A electro-chemical analyzer (CH Instruments, Inc., Austin, Texas) by using $0.5 \mathrm{mmol} / \mathrm{L}$ solution of the synthesized ferrocenyl azobenzenes with $\mathrm{Bu}_{4} \mathrm{NBF}_{4}$ $(0.1 \mathrm{~mol} / \mathrm{L})$ as electrolyte. A glassy carbon electrode was used as the working electrode with a platinum electrode as counter electrode and a silver electrode as the reference electrode. The working electrode was polished with $0.05 \mu \mathrm{m} \mathrm{Al}_{2} \mathrm{O}_{3}$ paste followed by washing successively in alcohol and deionized water for $30 \mathrm{~s}$ under ultrasonication, and then dried at room atmosphere before use.

The UV-vis spectra of the synthesized compounds were recorded on a UV-vis Unico spectraphotometer. The concentration of the solution was $0.05 \mathrm{mmol} / \mathrm{L}$.

\subsection{Synthesis}

Chlorocarbonyl ferrocene and 1,1'-dichlorocarbonylferrocene were synthesized according to the reported method (Amer et al., 2013). 


\subsubsection{Synthesis of ferrocenyl azobenzene $\mathbf{1}$}

Disperse orange 3 (14.5 g, $0.06 \mathrm{~mol})$ was dissolved in $30 \mathrm{ml}$ freshly distilled THF in a dried two-necked round-bottom flask followed by the addition of $\mathrm{Et}_{3} \mathrm{~N}$ (5.5 ml, $\left.0.04 \mathrm{~mol}\right)$. Afterwards, a solution of chlorocarbonyl ferrocene ( $9.9 \mathrm{~g}, 0.04 \mathrm{~mol})$ in $30 \mathrm{ml}$ freshly distilled THF was added dropwise into the previous solution. The reaction mixture was stirred for $8 \mathrm{~h}$ at $25^{\circ} \mathrm{C}$. After stirring, the mixture was filtered to obtain the precipitate. The crude product was washed successively with alcohol and deionized water three times each to remove disperse orange 3 and triethylamine salt. The synthetic route for ferrocenyl azobenzene $\mathbf{1}$ is shown in Scheme 1.

FTIR: wavenumber $\left(\mathrm{cm}^{-1}\right)=490$ (Cp-Fe str.), $1520(\mathrm{C}=\mathrm{C}$ str. of benzene ring), $1720(\mathrm{~N}-\mathrm{H}$ str. of amide group), 3100 (C-H str. of the rings), and 3278 ( $\mathrm{C}=\mathrm{O}$ str. $)$.

${ }^{1} \mathrm{H}$ NMR (DMSO): $\delta(\mathrm{ppm})=4.99$ and 4.52 $\left(-\mathrm{C}_{5} \underline{\mathrm{H}}_{4}, 4 \mathrm{H}\right), 4.33\left(\mathrm{C}_{5} \underline{\mathrm{H}}_{5}, 5 \mathrm{H}\right), 8.06(-2 \mathrm{C} \underline{\mathrm{H}}-\mathrm{C}-\mathrm{N}$ $\left.=\mathrm{N}-\mathrm{C}_{6} \underline{\mathrm{H}}_{4}-\mathrm{NO}_{2}, 6 \mathrm{H}\right), 8.48(-\mathrm{NH}-\mathrm{C}-2 \mathrm{CH}-, 2 \mathrm{H})$, and $9.85(-\mathrm{NH}-, 1 \mathrm{H})$.

${ }^{13} \mathrm{C}$ NMR (DMSO): $\delta(\mathrm{ppm})=67\left(\mathrm{C}^{\mathrm{b}}\right), 68\left(\mathrm{C}^{\mathrm{d}}\right)$, $69\left(\mathrm{C}^{\mathrm{c}}\right), 78\left(\mathrm{C}^{\mathrm{a}}\right), 120\left(\mathrm{C}^{\mathrm{g}}\right), 123\left(\mathrm{C}^{\mathrm{k}}\right), 124\left(\mathrm{C}^{\mathrm{h}}\right), 125$ $\left(C^{\mathrm{l}}\right), 142\left(C^{\mathrm{f}}\right), 148\left(\mathrm{C}^{\mathrm{i}}\right), 149\left(\mathrm{C}^{\mathrm{m}}\right), 156\left(\mathrm{C}^{\mathrm{j}}\right), 169\left(\mathrm{C}^{\mathrm{e}}\right)$.

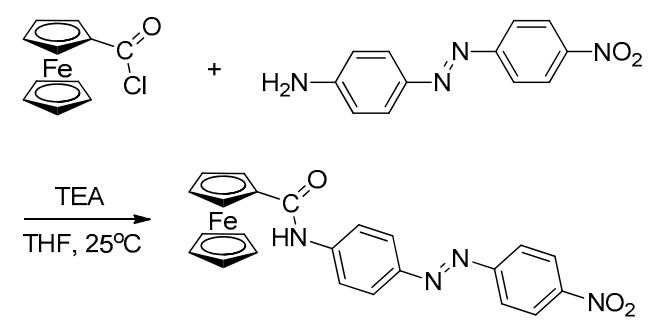

Scheme 1 Synthetic route of ferrocenyl azobenzene 1

\subsubsection{Synthesis of ferrocenyl azobenzene $\mathbf{2}$}

Ferrocenyl azobenzene 1 ( $0.4 \mathrm{~g}, 0.9 \mathrm{mmol})$ was dissolved in $100 \mathrm{ml}$ THF in a two-necked round-bottom flask. Sodium sulfide nonahydrate (1.7 g, $7.1 \mathrm{mmol})$ was dissolved in mixed solvents (20 $\mathrm{ml}$ deionized water and $10 \mathrm{ml} \mathrm{THF}$ ), then added to the previous solution. The reaction mixture was stirred at $80{ }^{\circ} \mathrm{C}$ for $20 \mathrm{~h}$. The mixture was then immediately filtered to remove the precipitate. The filtrate was evaporated on a rotary evaporator to get a crude product. The final product was obtained after removal of the sodium sulfide nonahydrate by washing the crude product with deionized water. The synthetic route of ferrocenyl azobenzene $\mathbf{2}$ is shown in Scheme 2.

FTIR: wavenumber $\left(\mathrm{cm}^{-1}\right)=490$ (Cp-Fe str.), $1520(\mathrm{C}=\mathrm{C}$ str. of benzene ring), $1720(\mathrm{~N}-\mathrm{H}$ str. of amide group), 3100 (C-H str. of the rings), and 3278 ( $\mathrm{C}=\mathrm{O}$ str.).

${ }^{1} \mathrm{H}$ NMR (DMSO): $\delta(\mathrm{ppm})=4.36\left(\mathrm{C}_{5} \underline{\mathrm{H}}_{5}, 5 \mathrm{H}\right)$, 4.51 and $5.02\left(-\mathrm{C}_{5} \underline{\mathrm{H}}_{4}, 4 \mathrm{H}\right), 6.11\left(-\mathrm{N}_{2}, 2 \mathrm{H}\right), 6.71$ and $7.65\left(-\mathrm{C}_{6} \underline{\mathrm{H}}_{4}-\mathrm{NH}_{2}, 4 \mathrm{H}\right), 7.69$ and 7.81 $\left(-\mathrm{CO}-\mathrm{NH}-\mathrm{C}_{6} \underline{\mathrm{H}}_{4}-, 4 \mathrm{H}\right)$, and $9.69(-\mathrm{CO}-\mathrm{NH}-, 1 \mathrm{H})$.

${ }^{13} \mathrm{C}$ NMR (DMSO): $\delta(\mathrm{ppm})=67\left(\mathrm{C}^{\mathrm{b}}\right), 68\left(\mathrm{C}^{\mathrm{d}}\right)$, $69\left(\mathrm{C}^{\mathrm{c}}\right), 78\left(\mathrm{C}^{\mathrm{a}}\right), 114\left(\mathrm{C}^{\mathrm{l}}\right), 121\left(\mathrm{C}^{\mathrm{k}}\right), 123\left(\mathrm{C}^{\mathrm{g}}\right), 125$ $\left(C^{\mathrm{h}}\right), 141\left(\mathrm{C}^{\mathrm{f}}\right), 142\left(\mathrm{C}^{\mathrm{j}}\right), 149\left(\mathrm{C}^{\mathrm{i}}\right), 169\left(\mathrm{C}^{\mathrm{e}}\right)$, and 152 $\left(\mathrm{C}^{\mathrm{m}}\right)$.

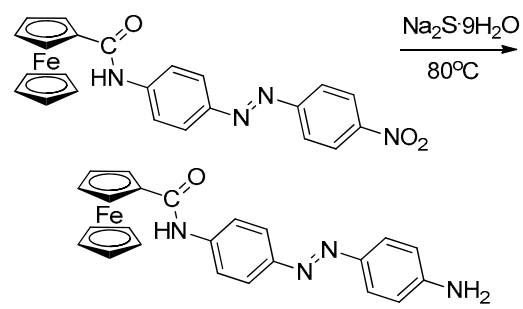

Scheme 2 Synthetic route of ferrocenyl azobenzene 2

\subsubsection{Synthesis of ferrocenyl azobenzene $\mathbf{3}$}

Disperse orange $3(6.0 \mathrm{~g}, 24.9 \mathrm{mmol})$ was dissolved in $100 \mathrm{ml}$ freshly distilled THF in a dried two-necked round-bottom flask followed by the addition of $\mathrm{Et}_{3} \mathrm{~N}$ (2.3 ml, $\left.16.6 \mathrm{mmol}\right)$. Afterwards, a solution of 1,1'-dichloro-carbonylferrocene (2.6 g, $8.3 \mathrm{mmol}$ ) in $50 \mathrm{ml}$ freshly distilled THF was added dropwise into the previous solution. The reaction mixture was stirred at $25^{\circ} \mathrm{C}$ for $8 \mathrm{~h}$. After stirring, the mixture was filtered to obtain the precipitate. The precipitate was washed successively with alcohol and deionized water to remove disperse orange 3 and the triethylamine salt. The synthetic route for ferrocenyl azobenzene 3 is shown in Scheme 3.

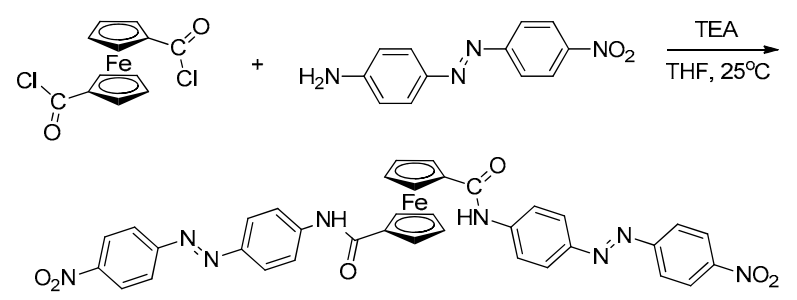

Scheme 3 Synthetic route of ferrocenyl azobenzene 3 
FTIR: wavenumber $\left(\mathrm{cm}^{-1}\right)=490(\mathrm{Cp}-\mathrm{Fe}$ str. $)$, $1520(\mathrm{C}=\mathrm{C}$ str. of benzene ring), $1720(\mathrm{~N}-\mathrm{H}$ str. of amide group), 3100 (C-H str. of the rings), and 3278 $(\mathrm{C}=\mathrm{O}$ str.).

${ }^{1} \mathrm{H}$ NMR (DMSO): $\delta(\mathrm{ppm})=4.56\left(-\mathrm{C}_{5} \underline{\mathrm{H}}_{4}, 4 \mathrm{H}\right)$, $5.23\left(-\mathrm{C}_{5} \underline{\mathrm{H}}_{4}, 4 \mathrm{H}\right), 7.75\left(-\mathrm{CONH}-\mathrm{C}_{6} \underline{\mathrm{H}}_{4}-\mathrm{C} \underline{\mathrm{H}}-, 12 \mathrm{H}\right)$, $8.26\left(-2 \mathrm{C} \underline{\mathrm{H}}-\mathrm{NO}_{2}, 4 \mathrm{H}\right)$, and $9.75(-\mathrm{CO}-\mathrm{N} \underline{\mathrm{H}}-, 2 \mathrm{H})$.

\section{Results and discussion}

\subsection{Synthesis and characterization of ferrocenyl azobenzenes}

Ferrocenyl azobenzene $\mathbf{1}$ and ferrocenyl azobenzene 3 were synthesized by an ammonolysis reaction of acyl chloride in freshly distilled THF, while ferrocenyl azobenzene $\mathbf{2}$ was synthesized by the reduction reaction of the nitro group of the ferrocenyl azobenzene 1 with sodium sulfide nonahydrate as a reducing agent in THF. The ${ }^{1} \mathrm{H}$ NMR and ${ }^{13} \mathrm{C}$ NMR spectra of the synthesized ferrocenyl azobenzenes are shown in Fig. 1 and Fig. 2, respectively.

Fig. 3 displays the FTIR spectra of the synthesized ferrocenyl azobenzene $\mathbf{1}, \mathbf{2}$, and $\mathbf{3}$. The assignment of the bands is as follows (Amer et al.,
2013). The spectra showed stretching vibration of $\mathrm{C}-\mathrm{H}$ of the cyclopentadienyl rings of the ferrocene moiety at $3100 \mathrm{~cm}^{-1}$. Characteristic bands of stretching vibration of $\mathrm{C}=\mathrm{O}$ and $\mathrm{N}-\mathrm{H}$ of amide group were observed at $3278 \mathrm{~cm}^{-1}$ and $1720 \mathrm{~cm}^{-1}$, respectively. The peaks at $1520 \mathrm{~cm}^{-1}$ and $490 \mathrm{~cm}^{-1}$ were assigned to the stretching vibration of $\mathrm{C}=\mathrm{C}$ in the phenyl and the stretching vibration of the cyclopentadienyl rings and iron atom. The absorptions manifested in the ${ }^{1} \mathrm{H}$ and ${ }^{13} \mathrm{C}$ NMR and FTIR spectra are in full agreement with the expected constitution of the synthesized products, which indicates that all the three compounds were synthesized successfully.

\subsection{Photo-chemical and redox properties of fer- rocenyl azobenzenes}

The synthesized ferrocenyl azobenzenes were expected to undergo reversible trans-cis isomerization by irradiation with UV and visible light due to the presence of the azobenzene group. Furthermore, ferrocene is well-known for its redox properties. Therefore, we investigated the photo- and electrochemical properties of the synthesized compounds by $\mathrm{UV}$ and $\mathrm{CV}$.

(a)

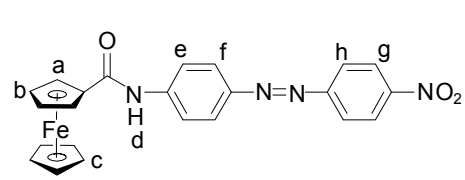

(b)
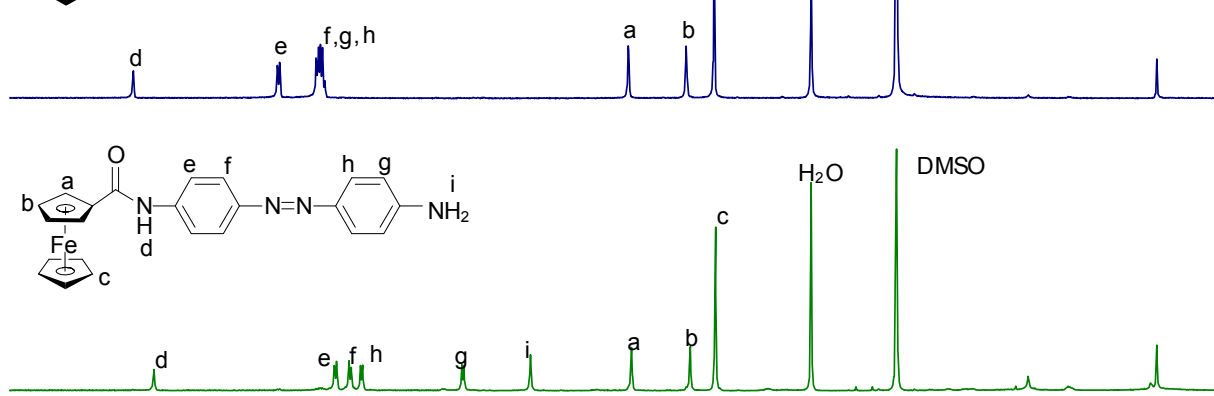

(c)

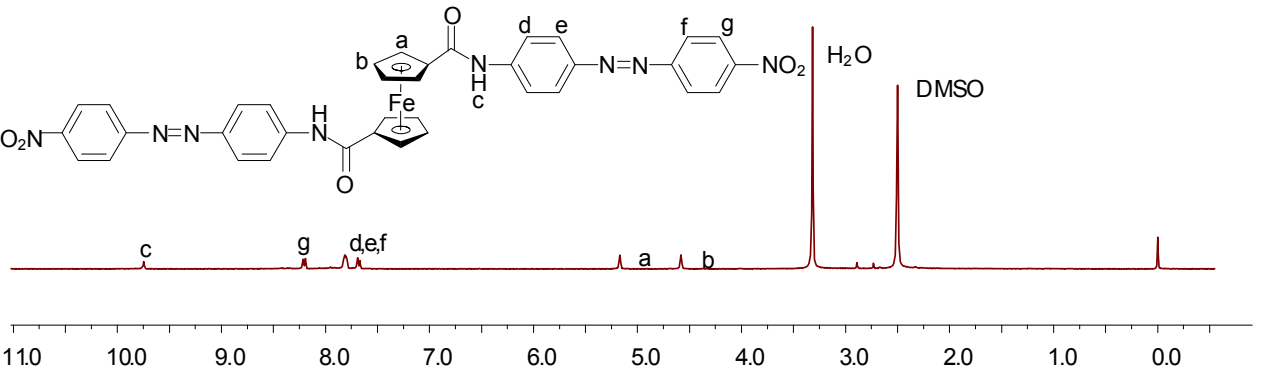

Fig. $1{ }^{1}$ H NMR spectra of ferrocenyl azobenzene 1 (a), ferrocenyl azobenzene 2 (b), and ferrocenyl azobenzene 3 (c) 
(a)
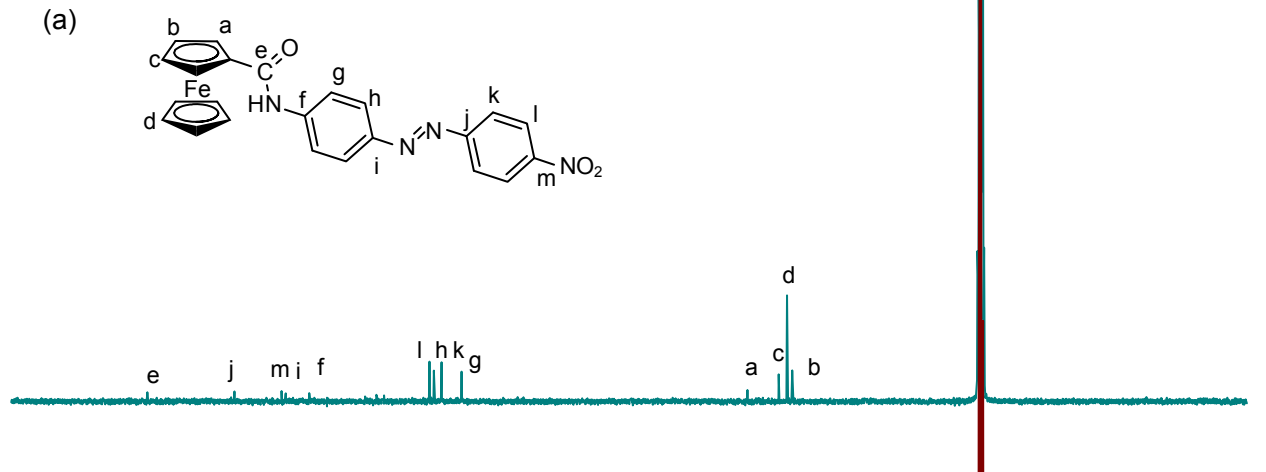

(b)
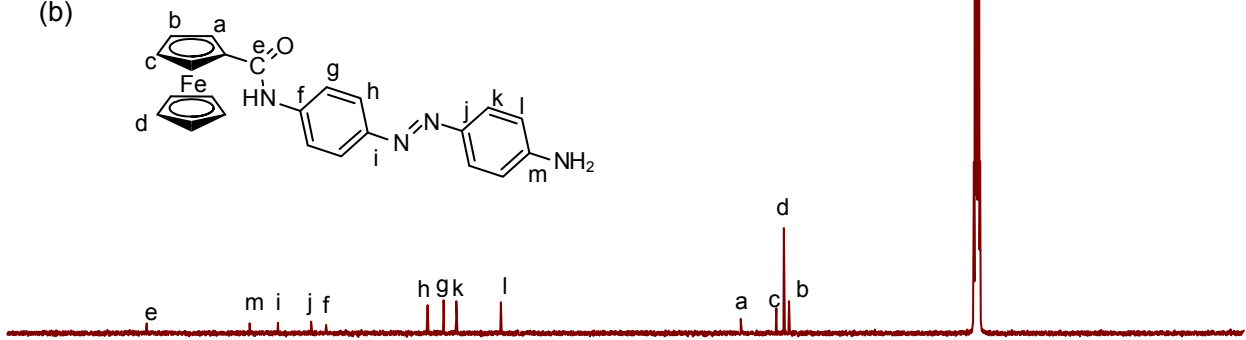

$\begin{array}{lllllllllllllllllll}180 & 170 & 160 & 150 & 140 & 130 & 120 & 110 & \begin{array}{c}100 \\ \mathrm{f} 1(\mathrm{ppm})\end{array} & 90 & 80 & 70 & 60 & 50 & 40 & 30 & 20 & 10 & 0\end{array}$

Fig. $2{ }^{13} \mathrm{C}$ NMR spectra of ferrocenyl azobenzene 1 (a) and ferrocenyl azobenzene 2 (b)

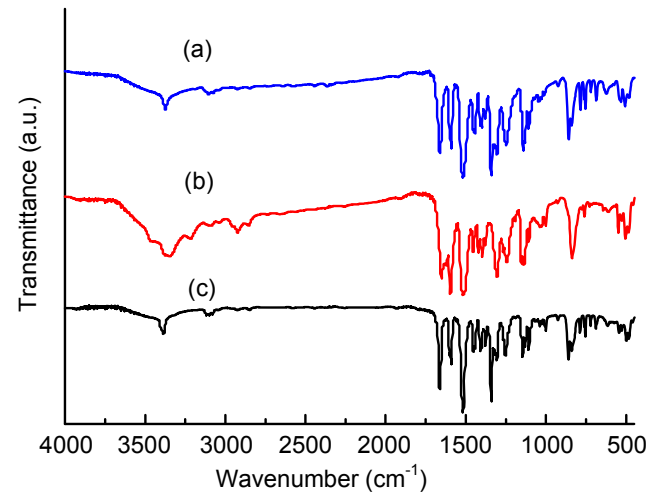

Fig. 3 FTIR spectra of ferrocenyl azobenzene 1 (a), ferrocenyl azobenzene 2 (b), and ferrocenyl azobenzene 3 (c)

It can be seen in Fig. 4 that ferrocenyl azobenzene showed the azo $\pi-\pi^{*}$ band at about $\lambda_{\max }=410 \mathrm{~nm}$ (Kurihara et al., 2002). The intensity of the azo $\pi-\pi^{*}$ band was decreased by UV irradiation, and almost reverted to its initial state by irradiation with visible light. This phenomenon is compatible with the characteristics of reversible trans-cis isomerization.

The synthesized ferrocenyl azobenzenes were electro-chemically active. However, the electric potential could be affected by many factors. We therefore investigated the effects of organic solvents, scan rate, and UV light irradiation on the electrochemical properties of the synthesized ferrocenyl azobenzenes by CV. From Fig. 5, it can be seen that organic solvents affected the electro-chemical behavior of ferrocenyl azobenzenes significantly. The ferrocenyl azobenzenes showed one pair of redox peaks in DCM. That pair related to the chemical structure in that only one redox center was present in each compound. However, several pairs of redox peaks were present in the CV spectra when ferrocenyl azobenzenes were dissolved in DMSO, which may be ascribed to interaction between DMSO and the synthesized compounds. Thus, DCM was chosen as the organic solvent in the following electrochemical studies of the synthesized compounds. Fig. 6 (p.150) implied that the redox current of the synthesized ferrocenyl azobenzenes increased with the increase of scan rate (from 0.1 to $0.5 \mathrm{~V} / \mathrm{s}$ ). Furthermore, it can be seen that the highest and the lowest peak-to-peak potential separations $\left(\Delta E_{\mathrm{p}}\right)$ of ferrocenyl 
azobenzene $\mathbf{1}$ and $\mathbf{2}$ were only a little higher than 59 $\mathrm{mV}$, which indicated nearly reversible electrochemical processes (Tan et al., 2009). However, the highest $\Delta E_{\mathrm{p}}$ was obtained for ferrocenyl azobenzene $\mathbf{3}$ in DCM, which indicated a totally irreversible redox process (Tan et al., 2007).

The effect of UV light irradiation on the redox behavior of the synthesized ferrocenyl azobenzenes
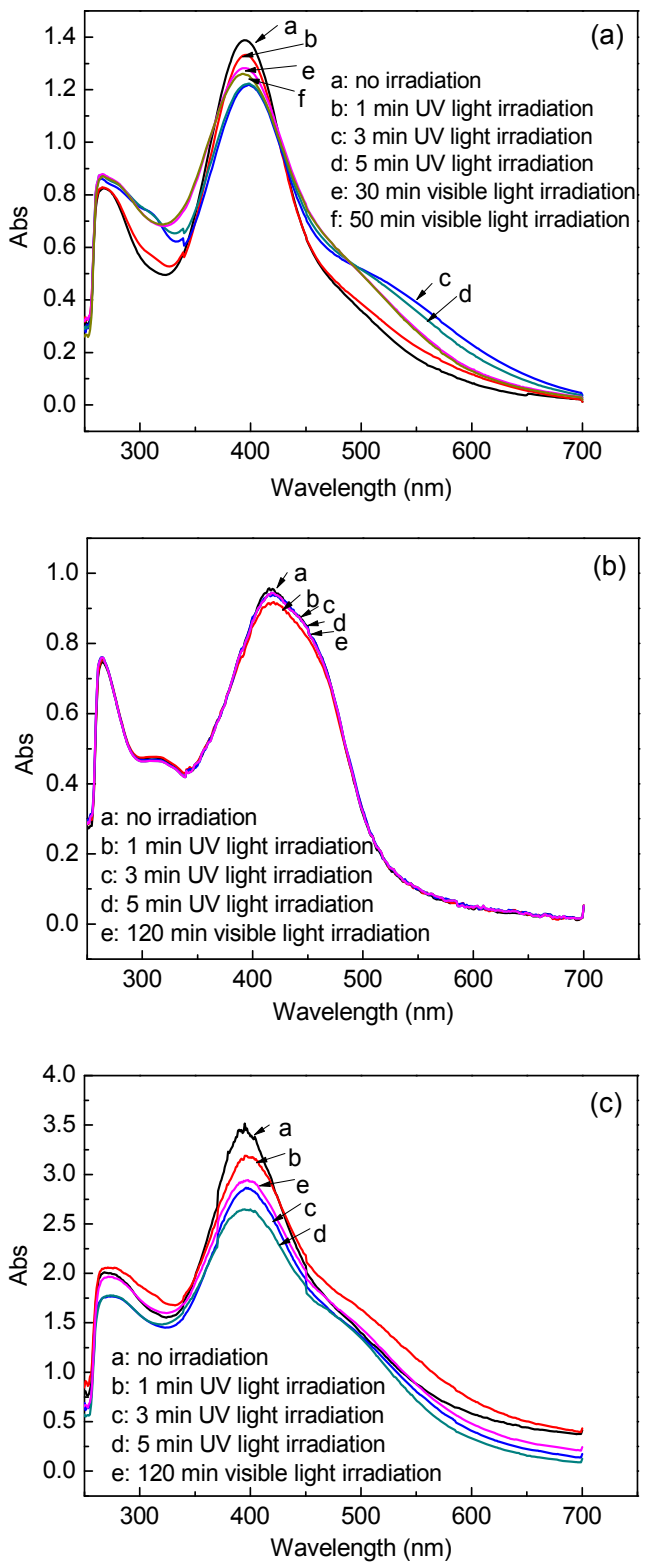

Fig. 4 UV spectra of ferrocenyl azobenzene 1 (a), ferrocenyl azobenzene 2 (b), and ferrocenyl azobenzene 3 (c) in DMSO under irradiation by different light sources was investigated by $\mathrm{CV}$. The results are shown in Fig. 7. From these results, we can say that the redox behavior of the synthesized compounds was influenced by UV irradiation, and is consistent with the results of UV-vis absorption spectra. From these results, it is reasonable to conclude that the synthesized ferrocenyl azobenzenes are photo- and electrochemically responsive materials.
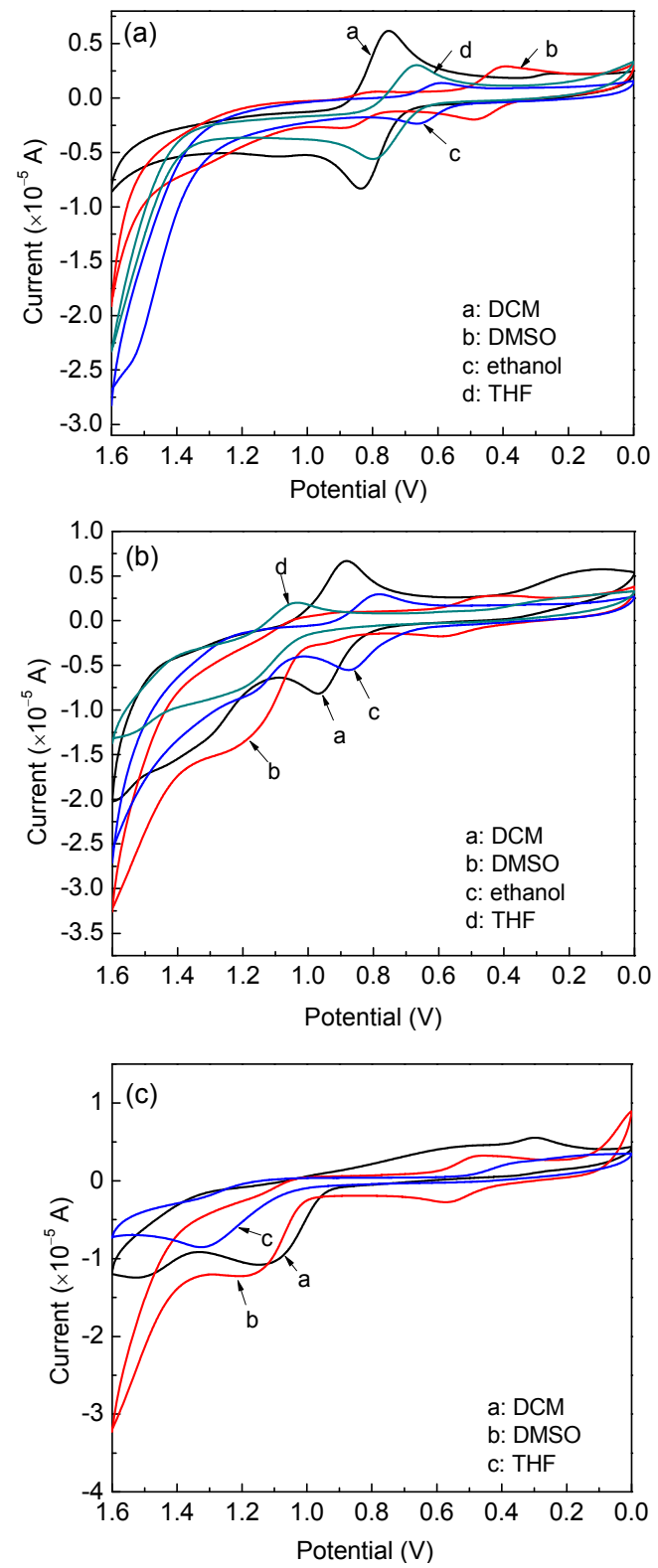

Fig. 5 Effect of different solvents on the $\mathrm{CV}$ behavior of ferrocenyl azobenzene 1 (a), ferrocenyl azobenzene 2 (b), and ferrocenyl azobenzene 3 (c) containing $0.1 \mathrm{~mol} / \mathrm{L} \mathrm{Bu}_{4} \mathrm{NBF}_{4}$ and $0.5 \mathrm{mmol} / \mathrm{L}$ ferrocenyl group at the scan rate of $0.1 \mathrm{~V} / \mathrm{s}$ 

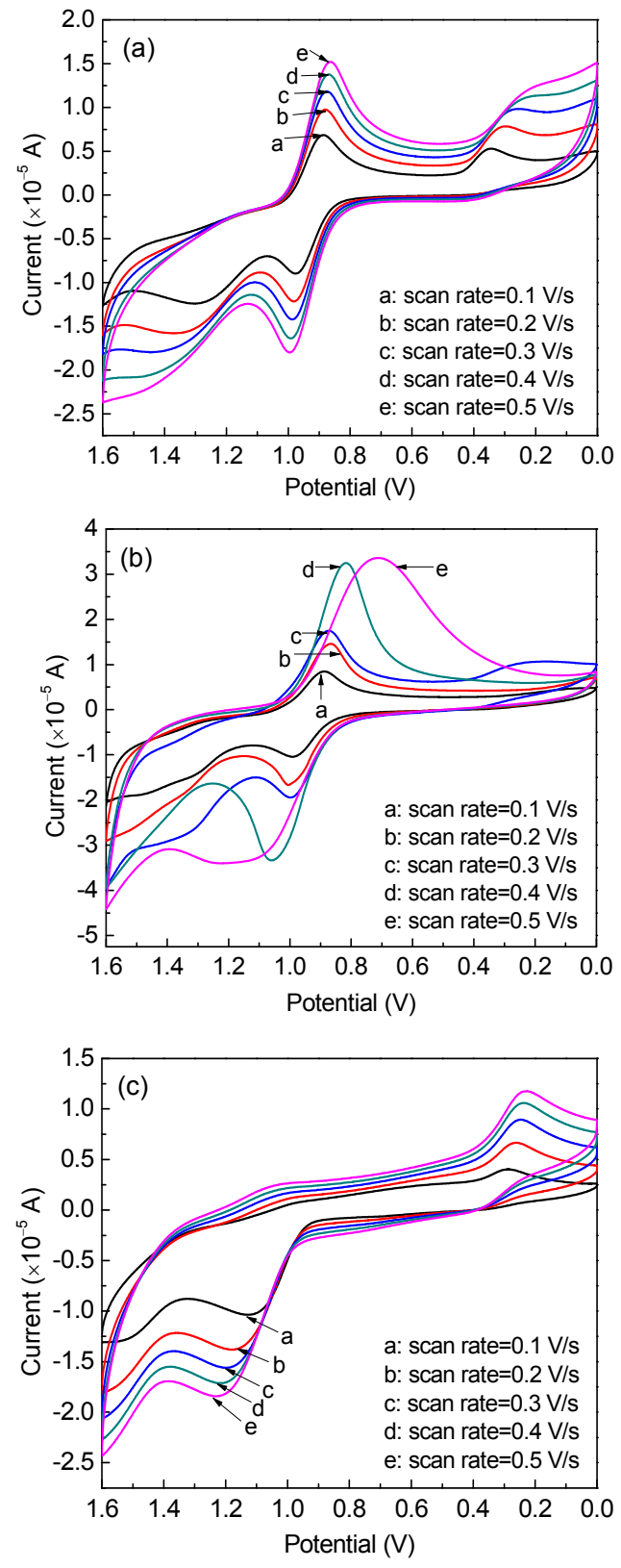

Fig. 6 Effect of scan rate on the $\mathrm{CV}$ behavior of ferrocenyl azobenzene 1 (a), ferrocenyl azobenzene 2 (b), and ferrocenyl azobenzene 3 (c) in DCM containing $0.1 \mathrm{~mol} / \mathrm{L}$ $\mathrm{Bu}_{4} \mathrm{NBF}_{4}$ and $0.5 \mathrm{mmol} / \mathrm{L}$ ferrocenyl group

\subsection{Anion recognition behavior of the synthesized ferrocenyl azobenzenes}

Anion recognition and sensing have become a keen interest of chemists and environmentalists due to their relevance to the environment and people's health (Deng et al., 2008; Tan et al., 2008). Generally, chemosensors are composed of anion
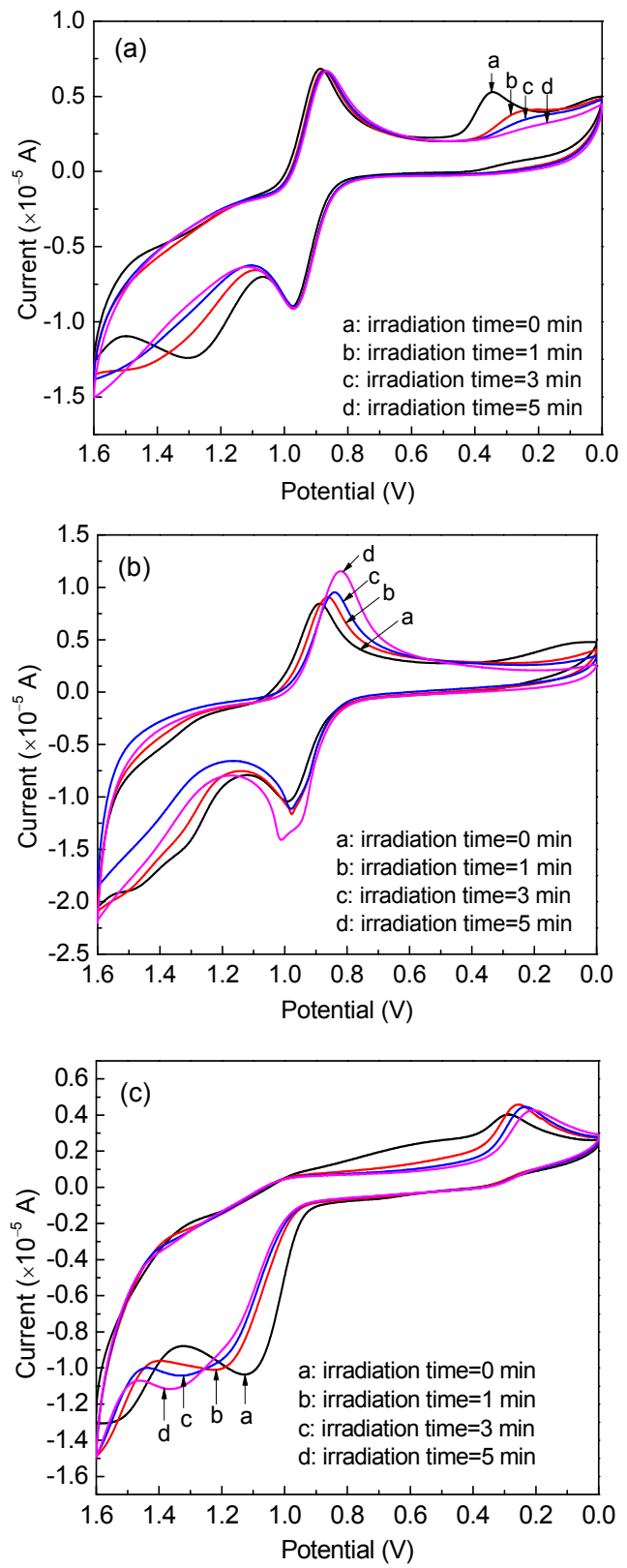

Fig. 7 Effect of UV light irradiation on the $\mathrm{CV}$ behavior of ferrocenyl azobenzene 1 (a), ferrocenyl azobenzene 2 (b), and ferrocenyl azobenzene 3 (c) in DMSO containing $0.1 \mathrm{~mol} / \mathrm{L} \mathrm{Bu}_{4} \mathrm{NBF}_{4}$ and $0.5 \mathrm{mmol} / \mathrm{L}$ ferrocenyl group at the scanning rate of $0.1 \mathrm{~V} / \mathrm{s}$

binding and signal transmission units. Here, we used the acyl amino group as an anion receptor due to its ability to form hydrogen bonds with specific anionic guests. Ferrocene and the azobenzene group served as effective signal transmission units due to their stable redox and photochemical properties, which have distinct advantages for detection. Compared with UV-vis absorption spectra and CV technique, 
color discrimination is the most feasible among analytical methods. To ensure the accuracy of results, all the above mentioned methods were applied to analyze the recognition behavior of ferrocenyl azobenzenes.

The synthesized ferrocenyl azobenzenes were titrated against $\mathrm{Br}^{-}, \mathrm{Cl}^{-}, \mathrm{F}^{-}, \mathrm{H}_{2} \mathrm{PO}_{4}{ }^{-}, \mathrm{HSO}_{4}{ }^{-}$, and $\mathrm{I}^{-}$in a mole ratio of 1:1 between ferrocenyl azobenzenes and anions, respectively. The recorded UV-vis absorption spectra and CV curves of ferrocenyl azobenzenes after titration are shown in Fig. 8 and
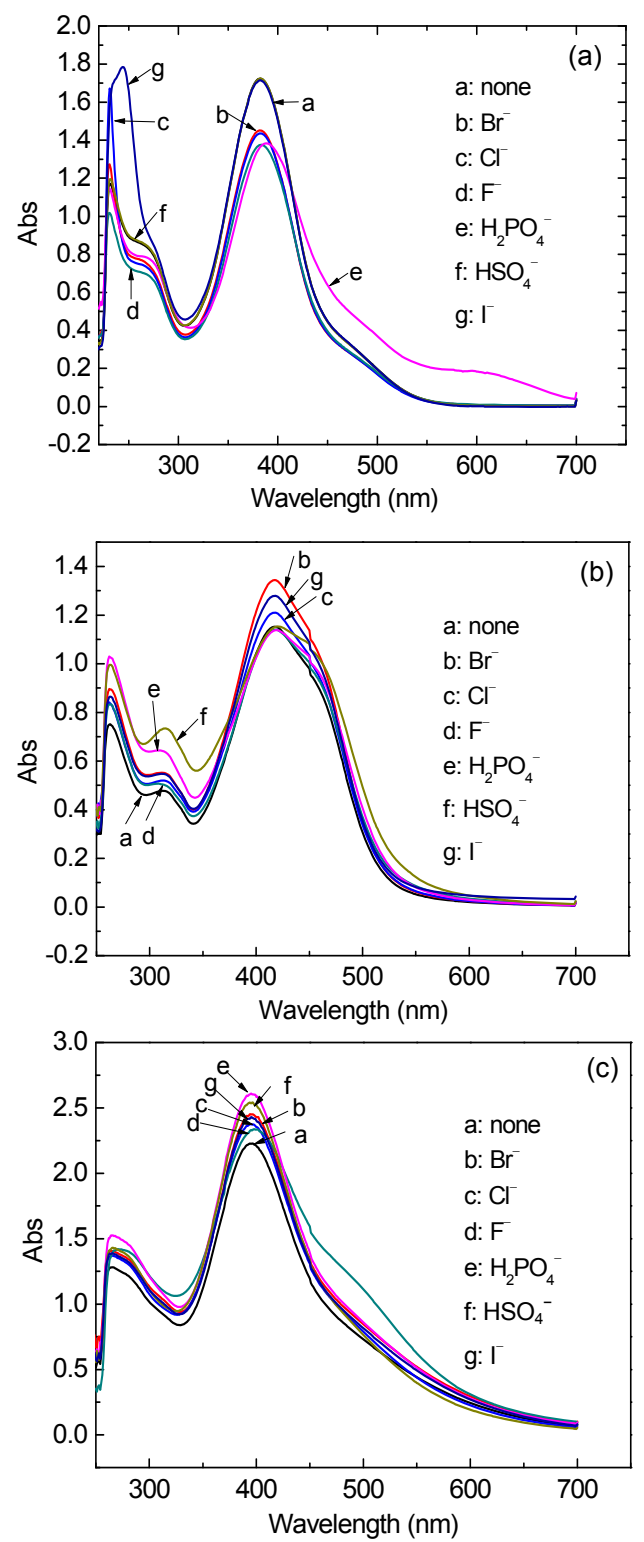

Fig. 8 UV-vis absorption spectra changes of ferrocenyl azobenzene 1 (a), ferrocenyl azobenzene 2 (b), and ferrocenyl azobenzene 3 (c) in DCM upon addition of different ions of 1 equiv. (none, $\mathrm{Br}^{-}, \mathrm{Cl}^{-}, \mathrm{F}^{-}, \mathrm{H}_{2} \mathrm{PO}_{4}^{-}, \mathrm{HSO}_{4}^{-}$, and $\mathrm{I}^{-}$)
Fig. 9, respectively. The titration of $\mathrm{F}^{-}$and $\mathrm{H}_{2} \mathrm{PO}_{4}{ }^{-}$in ferrocenyl azobenzene $\mathbf{1}$ and $\mathbf{3}$ caused an apparent change in the shape of absorption spectra, whereas little difference could be observed for ferrocenyl azobenzene 2 by the addition of anions. In addition, a series of ferrocenyl azobenzene solutions were prepared to investigate the colorimetric change by the addition of different anions in DCM, and the mole ratio was 1:4 (Fig. 10). As expected, the color of ferrocenyl azobenzene $\mathbf{1}$ and ferrocenyl azobenzene 3 changed from yellow to red-brown by the addition
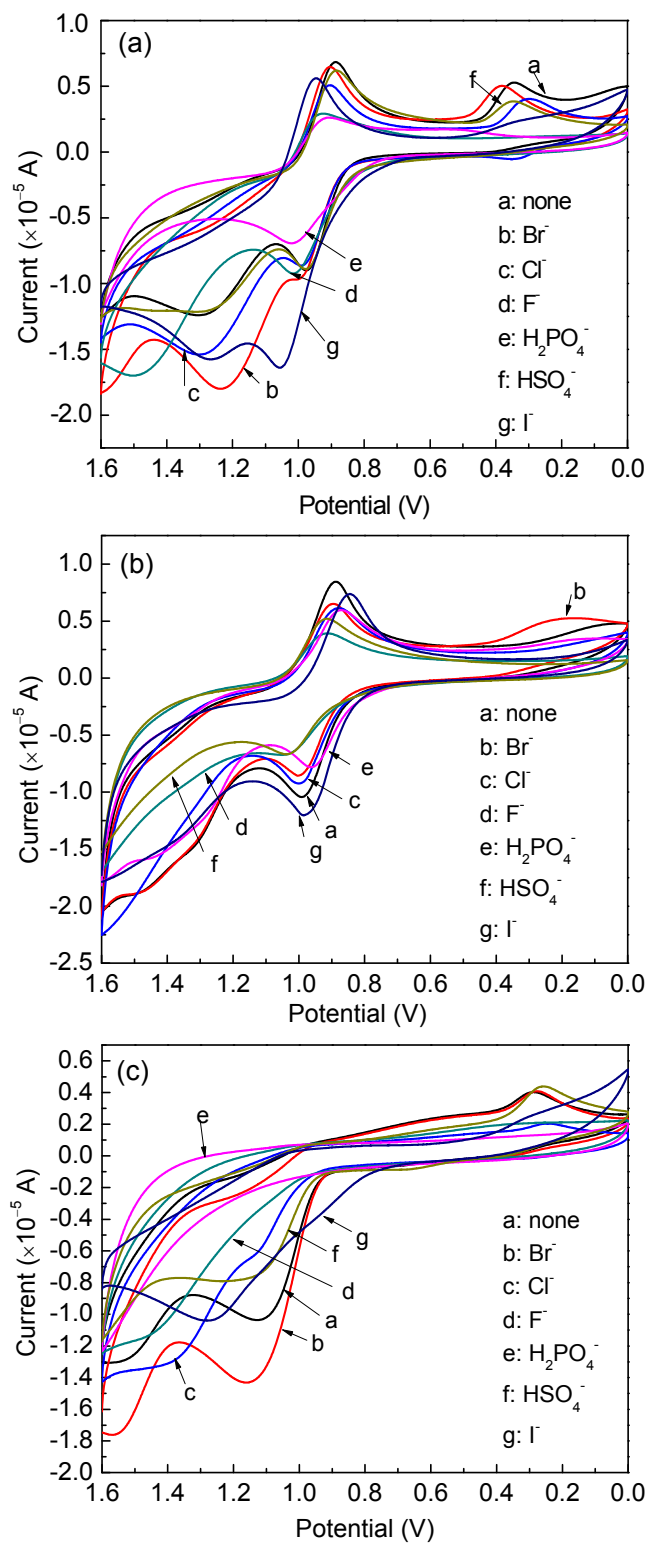

Fig. 9 CV behavior of ferrocenyl azobenzene 1 (a), ferrocenyl azobenzene 2 (b), and ferrocenyl azobenzene 3 (c) in DCM upon addition of different ions of 1 equiv. (none, $\mathrm{Br}^{-}, \mathrm{Cl}^{-}, \mathrm{F}^{-}, \mathrm{H}_{2} \mathrm{PO}_{4}^{-}, \mathrm{HSO}_{4}^{-}$, and $\mathrm{I}^{-}$) 
of $\mathrm{F}^{-}$and $\mathrm{H}_{2} \mathrm{PO}_{4}^{-}$. However, no obvious colorimetric change was observed for ferrocenyl azobenzene 2 .

These phenomena may be ascribed to the different effect of nitro and amino substituents on the benzene ring. As shown in Scheme 4, the nitro group caused an obvious charge transfer due to its electron attracting effect which resulted in an intensity sharpening of the hydrogen-bonding interaction (Zheng et al., 2011). Thus, it showed benign recognition to specific ions. On comparison with ferrocenyl azobenzene $\mathbf{1}$, ferrocenyl azobenzene $\mathbf{3}$ showed a more obvious colorimetric change upon addition of $\mathrm{F}^{-}$and $\mathrm{H}_{2} \mathrm{PO}_{4}^{-}$, which can be attributed to the presence of two strong electron-withdrawing substitutes and two binding units. However, ferrocenyl

(a)

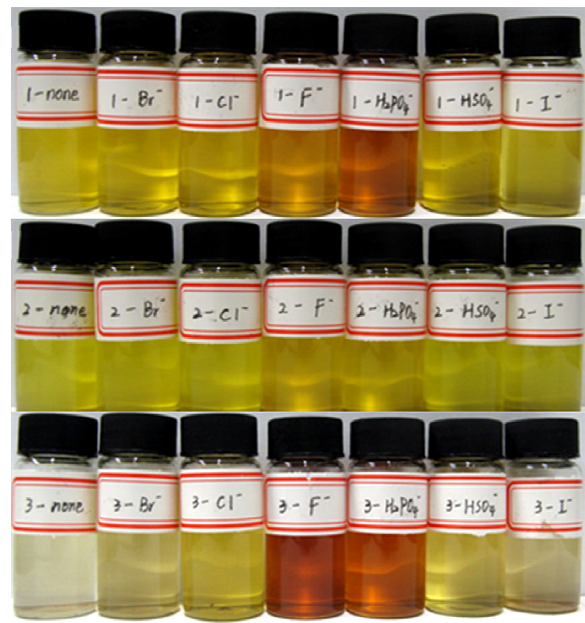

Fig. 10 Colorimetric changes of ferrocenyl azobenzene 1 (a), ferrocenyl azobenzene 2 (b), and ferrocenyl azobenzene 3 (c) in DCM upon addition of different ions of 4 equiv. (none, $\mathrm{F}^{-}, \mathrm{Cl}^{-}, \mathrm{Br}^{-}, \mathrm{I}^{-}, \mathrm{H}_{2} \mathrm{PO}_{4}^{-}$, and $\mathrm{HSO}_{4}{ }^{-}$). Note: for interpretation of the references to color in this figure, the reader is referred to the web version of this article

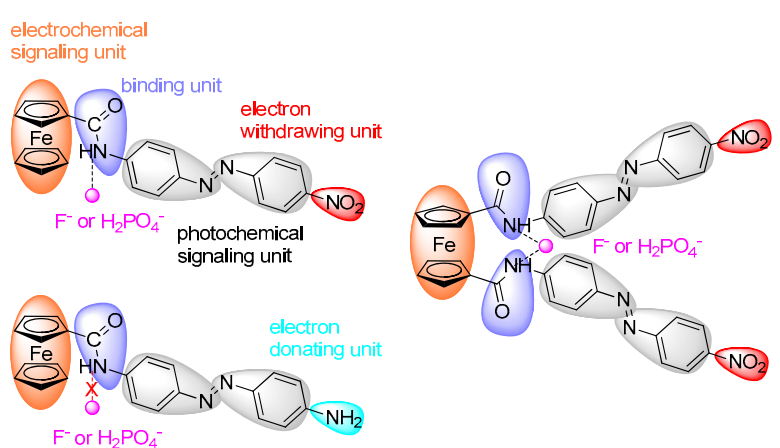

Scheme 4 Plausible mechanism of anion recognition processes of the synthesized ferrocenyl azobenzenes upon addition of $\mathrm{F}^{-}$and $\mathrm{H}_{2} \mathrm{PO}_{4}^{-}$ azobenzene 2 substituted with an amino group showed weak recognition ability because of its electro effect which weakens the hydrogen bonding. On the basis of these results, we can say that ferrocenyl azobenzene $\mathbf{1}$ and $\mathbf{3}$ are promising candidates for selective recognition of $\mathrm{F}^{-}$and $\mathrm{H}_{2} \mathrm{PO}_{4}^{-}$, while ferrocenyl azobenzene 2 shows little recognition behavior towards those anions.

\section{Conclusions}

Three ferrocene- and azobenzene-based compounds linked with an acyl amino group were successfully synthesized. The anion recognition behaviors of the synthesized ferrocenyl azobenzenes with specific guest anions based on hydrogen bonding were studied by electro- and photo-chemical techniques. The results showed that ferrocenyl azobenzene 1 and ferrocenyl azobenzene 3 exhibited high binding affinity and sensitivity for $\mathrm{F}^{-}$and $\mathrm{H}_{2} \mathrm{PO}_{4}^{-}$, while ferrocenyl azobenzene 2 was not sensitive to $\mathrm{F}^{-}$and $\mathrm{H}_{2} \mathrm{PO}_{4}^{-}$, as little change could be observed in the absorption spectrum or by naked-eye detection. These interesting phenomena may well be caused by different substituents on the receptor compounds. The nitro substituent, an electron withdrawing one, showed a positive effect on the binding sensitivity toward $\mathrm{F}^{-}$and $\mathrm{H}_{2} \mathrm{PO}_{4}^{-}$due to the strong hydrogen bonding between the receptor and the guest, while the electron-donating amino group substituent decreased the sensitivity of the sensor. Further studies will be needed to explore the effect of the substituent on the recognition behaviors.

\section{References}

Amer, W.A., Yu, H.J., Wang, L., et al., 2013. Synthesis, characterization and properties of some main-chain ferrocene-based polymers containing aromatic units. Journal of Inorganic and Organometallic Polymers and Materials, 23(6):1431-1444. http://dx.doi.org/10.1007/s10904-013-9946-2

Apreutesei, D., Mehl, G.H., Scutaru, D., 2007. Ferrocenecontaining liquid crystals bearing a cholesteryl unit. Liquid Crystals, 34(7):819-831. http://dx.doi.org/10.1080/02678290701478715

Beer, P.D., Graydon, A.R., Johnson, A., et al., 1997. Neutral ferrocenoyl receptors for the selective recognition and sensing of anionic guests. Inorganic Chemistry, 36(10): 2112-2118. http://dx.doi.org/10.1021/ic961401b 
Carlescu, I., Scutaru, A.M., Apreutesei, D., et al., 2007. The liquid crystalline behaviour of ferrocene derivatives containing azo and imine linking groups. Liquid Crystals, 34(7):775-785. http://dx.doi.org/10.1080/02678290701343190

Deng, L.B., Wang, L., Huo, J., et al., 2008. Preparation of $N, N^{\prime}$-bisethoxyethane[12] amideferrocenophane and its application in anion recognition. Journal of Physical Chemistry B, 112(17):5333-5337. http://dx.doi.org/10.1021/jp710824a

Ikeda, T., Tsutsumi, O., 1995. Optical switching and image storage by means of azobenzene liquid-crystal films. Science, 268(5219):1873-1875. http://dx.doi.org/10.1126/science.268.5219.1873

Kumar, G.S., Neckers, D.C., 1989. Photochemistry of azobenzene-containing polymers. Chemical Reviews, 89(8):1915-1925. http://dx.doi.org/10.1021/cr00098a012

Kuo, L.J., Liao, J.H., Chen, C.T., et al., 2003. Two-arm ferrocene amide compounds: synclinal conformations for selective sensing of dihydrogen phosphate ion. Organic Letters, 5(11):1821-1824. http://dx.doi.org/10.1021/o1034364i

Kurihara, M., Hirooka, A., Kume, S., et al., 2002. Redoxconjugated reversible isomerization of ferrocenylazobenzene with a single green light. Journal of the American Chemical Society, 124(30):8800-8801. http://dx.doi.org/10.1021/ja026625+

Kurosawa, M., Takuya, N., Takayuki, M., et al., 1999. Synthesis of azo-bridged ferrocene oligomers and a polymer and electrochemical and optical analysis of internuclear electronic interactions in their mixed-valence states. Inorganic Chemistry, 38(22):5113-5123. http://dx.doi.org/10.1021/ic990646w

Li, C., Wang, L., Yu, H.J., et al., 2013. Synthesis of novel colorimetric probe molecules and their application in anion recognition based on strong hydrogen bond. Journal of Organometallic Chemistry, 726:32-36. http://dx.doi.org/10.1016/j.jorganchem.2012.12.012

Lisa, G., Wilson, D.A., Scutaru, D., et al., 2010. Investigation of thermal degradation of some ferrocene liquid crystals. Thermochimica Acta, 507-508(8):49-59. http://dx.doi.org/10.1016/j.tca.2010.04.030

Manners, I., 1999. Poly(ferrocenylsilanes): novel organometallic plastics. Chemical Communications, (10):857-865. http://dx.doi.org/10.1039/a810043h

Miyaji, H., Collinson, S.R., Prokes I., et al., 2003. A ditopic ferrocene receptor for anions and cations that functions as a chromogenic molecular switch. Chemical Communications, (1):64-65. http://dx.doi.org/10.1039/b210227g

Muraoka, T., Kinbara, K., Aida, T., 2006. Mechanical twisting of a guest by a photoresponsive host. Nature, 440(7083): 512-515. http://dx.doi.org/10.1038/nature04635

Muraoka, T., Kinbara, K., Aida, T., 2007. Reversible operation of chiral molecular scissors by redox and UV light.
Chemical Communications, (14):1441-1443.

http://dx.doi.org/10.1039/b618248h

Namiki, K., Murata, M., Kume, S., et al., 2011. Synthesis of photo-switchable 3-FcAB-modified polymer particles. New Journal of Chemistry, 35(10):2146-2152. http://dx.doi.org/10.1039/c1nj20189a

Natansohn, A., Rochon, P., 2002. Photoinduced motions in azo-containing polymers. Chemical Reviews, 102(11): 4139-4175. http://dx.doi.org/10.1021/cr970155y

Onofrei, R.M., Carlescu, I., Lisa, G., et al., 2012. Synthesis and liquid crystalline behavior of some monosubstituted ferrocene containing schiff bases. Revista De Chimie, 63(2):139-145.

Onofrei, R.M., Carlescu, I., Epure, L., et al., 2013. Synthesis and liquid crystalline properties of some esters of 4-ferrocenyl-4'-hydroxyazobenzene. Acta Chimica Slovenica, 60(3):604-616.

Oton, F., Tarraga, A., Velasco, M., et al., 2004. A new fluoride selective electrochemical and fluorescent chemosensor based on a ferrocene-naphthalene dyad. Chemical Communications, 14:1658-1659. http://dx.doi.org/10.1039/b404601c

Reynes, O., Bucher, C., Moutet, J.C., et al., 2004. Redox sensing of anions in pure aqueous environment by ferrocene-containing 4,4'-bipyridinium-based receptors and polymer films. Chemical Communications, 4:428-429. http://dx.doi.org/10.1039/b314236a

Sakamoto, A., Hirooka, A., Namiki, K., et al., 2005. Photon-, electron-, and proton-induced isomerization behavior of ferrocenylazobenzenes. Inorganic Chemistry, 44(21): 7547-7558. http://dx.doi.org/10.1021/ic051184r

Seibold, E.A., Sutton, L.E., 1955. Structure of ferrocene. Journal of Chemical Physics, 23(10):1967. http://dx.doi.org/10.1063/1.1740629

Shafir, A., Power, M.P., Whitener, G.D., et al., 2000. Synthesis, structure, and properties of 1,1'-diamino- and 1,1'diazidoferrocene. Organometallics, 19(19):3978-3982. http://dx.doi.org/10.1021/om0004085

Sola, A., Tarraga, A., Molina, P., 2012. A ferrocenylguanidine derivative as a highly selective electrochemical and colorimetric chemosensor molecule for acetate anions. Dalton Transactions, 41(27):8401-8409. http://dx.doi.org/10.1039/c2dt30632h

Szymanska, I., Radecka, H., Radecki, J., et al., 2006. Ferrocene-substituted calix[4]pyrrole modified carbon paste electrodes for anion detection in water. Journal of Electroanalytical Chemistry, 591(2):223-228. http://dx.doi.org/10.1016/j.jelechem.2006.04.007

Tan, Q.H., Wang, L., Yu, H.J., et al., 2007. Study on synthesis and electrochemical properties of a novel ferrocenebased compound and its application in anion recognition. Journal of Physical Chemistry B, 111(15): 3904-3909. http://dx.doi.org/10.1021/jp068289f 
Tan, Q.H., Wang, L., Ma, L., et al., 2008. Study on anion electrochemical recognition based on a novel ferrocenyl compound with multiple binding sites. Journal of Physical Chemistry B, 112(35):11171-11176. http://dx.doi.org/10.1021/jp805002a

Tan, Q.H., Wang, L., Ma, L., et al., 2009. Electrochemical behaviors and anion recognition of ferrocene modified hyperbranched polyether. Macromolecules, 42(13): 4500-4510. http://dx.doi.org/10.1021/ma900094p

Thomas, J.L., Howarth, J., Hanlon, K., et al., 2000. Ferrocenyl imidazolium salts as a new class of anion receptors with $\mathrm{C}-\mathrm{H}$ center dot center dot center dot X-hydrogen bonding. Tetrahedron Letters, 41(3):413-416. http://dx.doi.org/10.1016/S0040-4039(99)02072-9

Villoslada, R., Alonso, B., Casado, C.M., et al., 2009. Anion receptor electrochemical sensing properties of poly(propyleneimine) dendrimers with ferrocenylamidoalkyl terminal groups. Organometallics, 28(3): 727-733. http://dx.doi.org/10.1021/om8007019

Yoon, J., Kim, S.K., Singh, N.J., et al., 2006. Imidazolium receptors for the recognition of anions. Chemical Society Reviews, 35(4):355-360.

http://dx.doi.org/10.1039/b513733k
Zheng, W.R., Li, J., Huang, T., et al., 2011. Hydrogen bonding interaction between ureas or thioureas and nitrocompounds. Research on Chemical Intermediates, 37(1): 31-45.

http://dx.doi.org/10.1007/s11164-010-0230-6

\section{中文概要}

题 目: 用于阴离子识别的二茂铁基偶氮苯化合物的 合成

目 的：研究二茂铁基偶氮苯化合物的光电响应性能及 离子识别性能, 并研究取代基对其离子识别性能 的影响。

创新点：考察取代基对于二茂铁基偶氮苯化合物的影响, 并提出可能的机理。

方 法: 循环伏安 (CV) 法和紫外可见吸收光谱 (UV-vis) 法。

结 论: 通过 CV 法和 UV-vis 法研究二茂铁基偶氮苯化 合物的离子识别性能, 发现硝基取代的化合物对 于 $\mathrm{F}^{-}$和 $\mathrm{H}_{2} \mathrm{PO}_{4}{ }^{-}$具有选择性离子识别作用, 而氨 基取代的化合物则识别作用不明显。

关键词：二茂铁; 偶氮苯; 光电响应; 离子识别 